\title{
Galactagogue action of Nigella sativa seeds
}

\author{
${ }^{1,}$ Profesor Ali Esmail Al-Snafi, ${ }^{2,}$ Assist profesor Wajdy J Majid, \\ ${ }^{3,}$ Lecturer Tayseer Ali Talab, \\ ${ }^{1,}$ Dept. Pharmacology, Thiqar College of medicine \\ ${ }^{2,}$ Dept. Biochemistry, Thiqar college of medicine. \\ ${ }^{3,}$ Dept. Pharmacology, Thiqar college of medicine.
}

\begin{abstract}
This experimental study was designed to determine the galactagogue action of Nigellasativaseeds.

LactatingmicewereswitchedontoNigellasativacontainingdietfromthedayoflabourandfor15days.

Nigellasativasignificantly $(P<0.0 l)$ increased serum prolact in level and the weight of the Litter compared with controlgroup. Breasttissues of lactatingmicekepton Nigellasativacontain ingdietshowedlargeracini, thickerepitheliaandhyperactivity.Nohaematological,histologicalandbiochemicalsideeffectswerecausedbyNigella sativa.
\end{abstract}

Key words: Nigella sativa, galactagogue, milk letdown

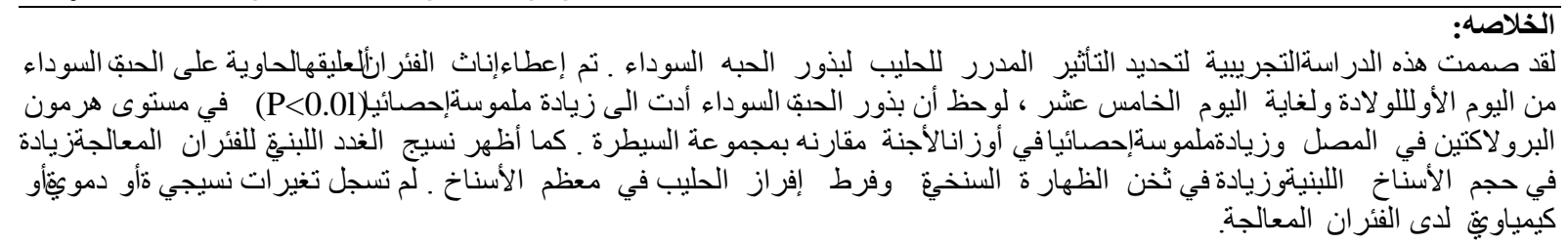

\section{INTRODUCTION}

Nigella sativa Linn (Black Cumin) is widely cultivated throughout South Europe, Syria, Egypt, Saudi Arabia, Turkey, Iran, Pakistan and India ${ }^{(1)}$. A1- Jassir has reported in detail the chemical composition of Nigellasativa seeds, theanalysisshowed a composition of $20.85 \%$ protein, $38.20 \%$ fat, $4.64 \%$ mosit'ure, $4.37 \%$ ash, $7.94 \%$ crude fiber and $31.94 \%$ total carbohydrates ${ }^{(2)}$. Sodium iron, zinc, calcium, magnesium, manganese and, copper were detected in Nigella sativa seeds at low levels, while lead, cadmium and arsenic were not present $^{(2,3) .}$ Chemical analysis of Nigella sativa fats, revealed a composition of myristic, palmitic, stearic, oleic, linoleic and arachidonic acids ${ }^{(2,3)}$. However 67 compoundswereidentified ,by capillalygaschromatography of Nigella sativa oils.They contained p-cymene $31.7 \%$, a- pinene $9.3 \%$,thymoquinone $24.5 \%$ and many othercompounds ${ }^{(1)}$. Nigella sativa carbohydrates consisted mainly of sucurose $32.56 \%$, fructose $21.72 \%, \alpha-$ glucose $20.81 \%$ and $\beta$-glucose $11.68 \%{ }^{(3)}$. Analysis ofNigella proteins showed thatthey consisted of 15 amino acidsincluding 9 essentialaminoacids ${ }^{(1)}$. Nigella sativa seeds exerted many pharmacological effects, theseinclude antibacterial $^{(3-5)}$.antifungal ${ }^{(3)}$, bronchodilator ${ }^{(6-7)}$,inhibititon ofhistamine release from mast cells ${ }^{(3,8)}$, anticholinergic and smooth musclerelaxant effects ${ }^{(9)}$, ,ardiac depressant, hypotensive effects ${ }^{(10,11)}$, ,ypoglycemic effects $^{(12)}$, immunostimulant ${ }^{(13,14)}$ and anticancereffects ${ }^{(15)}$.This study was designed to determine the galactagogue action of Nigellasativa seed and itssafety.

\section{Materials and Methods:}

Sixty mature female albino mice, of approximately similar bodyweightand agewereused in thisstudy. Theregularity ofestruscycleofthefemaleswasdeterminedby vaginalsmearstained by methyleneblue. Thenthe femaleswere mated with healthy malesofthe same strain, during theproestrusperiodandfor $24 \mathrm{hrs}$. Thedayoffertilization,asdeterminedbythe presenceofthesperm inthevaginal smears, wasconsidered asday 1ofthepregnancy. After labour,12 femaleswereexcluded becausethey gavelessthan 3 fetuses.The rest 48 femaleswere divided into 2 groupsof 24 each.The litter size was reduced to 3 fetuses for each female. Fetuses wereweighedand thenthe mothers ineach groupwereswitchedon controldiet orNigella sativa diet.Thedietwasprepared according to Agrawalaet $a l^{(17)}$. 


\section{Controldiet (1kg.) Nigella sativa containing diet (1kg.)}

Wholewheatflour 800gr. Wholewheatflour 700gr

Wholemilk powder 170gr. Wholemilkpowder 170gr.

Yeast 22gr.Nigellasativapowder 100gr.

Calcium carbonate $5 \mathrm{gr}$. Yeast 22gr.

Table salt 3 gr.Calcium carbonate $5 \mathrm{gr}$.

Multivitamins (SDI) 1capsule.

Table salt 3gr.

Multivitamins(SD1)1capsule

Aslitterliveon mother'smilk only for 20 daysand cannotnibbleat the food laid outforthem mothers ${ }^{(17)}$, the experimentlasted for 15 days. Atday 15,fetuses were weighed again.Blood sampleswere taken from onethirdofthemothersineachgrouptodetermineserum prolactinlevel(R1A-ClSbiointernational-France).Blood samplesofthesecondthird ofthemothers in each groups were used to estimate serum glucose, urea,GOT,GPT,bilirubin,uricacid,creatinine,triglycerides, alkalineand

acidphosphatasesbyanenzymaticmethods(Raudox).Bloodsamplesofthelastthird of the mothers were used to estimate WBC count, RBC count,differentialWBC countandHb .The breasttissues ofthe motherswere biopsied and processed forhistological examination. Specimens were taken from the liver, kidney,intestineandstomach forthepathologicalstudy.Studentt-testwasusedtodeterminethesignificancybetweengroups.

Results:

This study showed that serum prolactin level, oflactating femalemice kept on Nigella sativa containing diet, was significantly higher $(\mathrm{P}<0.01)$ than thatofmothersswitchedontocontroldiet(Table1).Theweight of the litter ofthefemaleskeptonNigella sativa containingdietwas significantly $(\mathrm{P}<0.01)$ higherthanthoseoffemale givencontroldiet(Table 2).In comparison with control group,thesectionsofthebreast

tissue of mothers kept on Nigella sativa containing dietshowed largeaciniwith an increaseintheproliferation andthicknessoftheepithelium. The majority ofthe aciniin the breasttissue showed moresecretaryactivity(Fig1).No pathological changes were observed in the liver,kidney,stomach andintestineoffemalesgivenNegillasativacontainingdiet.Allhematological and biochemicalvalues were not significantly changes. However, a slightreduction $(\mathrm{P}<0.05)$ intheserum glucoseanduricacid wasfound in females keptonNigellasativa containingdiet.

Table 1: Serum prolactin level in females given control diet in comparison of female kept on Nigella sativa containing diet.

\begin{tabular}{|l|c|c|}
\hline \multicolumn{1}{|c|}{ Groups } & No. of mice & Serum prolactin ng/ml 8 p.m \\
\hline Lactating mice on control diet & 8 & $175.50^{\bar{T}} 7.82$ \\
\hline $\begin{array}{l}\text { Lactating mice on Nigella sativa containing } \\
\text { diet }\end{array}$ & 8 & $185.0 \overline{\overline{+}} 3.16^{(\mathrm{p}<0.01)}$ \\
\hline
\end{tabular}

Table 2 : The increase in the weight of the litter of the female mice kept on Nigella sativa containing diet compared with control.

\begin{tabular}{|l|c|}
\hline \multicolumn{1}{|c|}{ Groups } & $\begin{array}{l}\text { The difference between the weight of the litter } \\
\text { at } 1^{\text {st }} \text { and } 15^{\text {th }} \text { day of age }(\mathrm{mg})^{*}\end{array}$ \\
\hline $\begin{array}{l}\text { The litter w eight of lactating mice on } \\
\text { control diet }\end{array}$ & $4730.25^{\bar{T}} 290.85$ \\
\hline $\begin{array}{l}\text { The litter weight of lactating mice on } \\
\text { Nigella sativa containing diet }\end{array}$ & $6168.66^{\overline{\boldsymbol{T}}} 341.49^{(\mathrm{P}<0.01)}$ \\
\hline
\end{tabular}

*Mean of the means of litter weight of all mothers in the group 

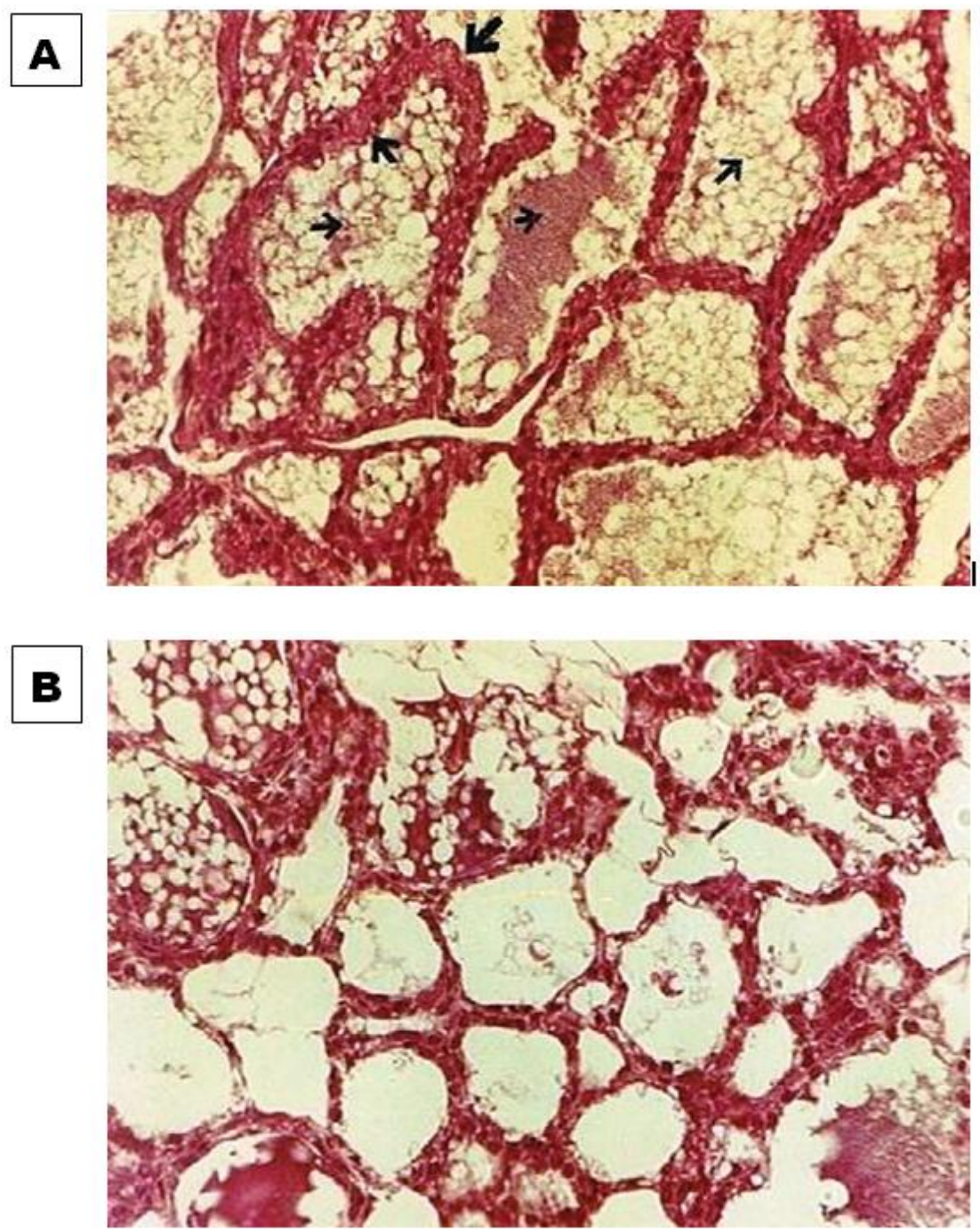

Fig.1: (A) Section on the breast tissue of the lactating mice kept on Nigella sativa containing diet showing larger acini $(\rightarrow)$,thicker epithelia $(\rightarrow)$, and more secretory activity $(\rightarrow)$, compared to the breast tissue of the lactating mice kept on control diet (B). (40X).

\section{Discussion:}

The prolactin stimulatory effect of Nigella sativa could be attributed to its anticholinergic effect ${ }^{(9)}$ .Snyder et al found thatlactotrophs contained muscarinic receptors,and the administration ofcholinergic muscarinicagonistdecreased the prolactin secretion eitherin basalcondition orafterdifferentstimuli ${ }^{(18)}$, in addition tothisdirectmuscarinic effect at the level of lactotrophs, acetylcholine also seems to inhibit prolactin release at the level of hypothalamus ${ }^{(19)}$. On theotherhand,nigellone,the carbonyl polymer ofthymoquinoneisolated from Nigellasativa,is a very effective histamine releaseinhibitor.Thisinhibition ismediated by decreasing intracellularcalcium,inhibition ofprotein kinase $\mathrm{C}$ and inhibition of oxidative metabolism ${ }^{(8)}$. Histamineisan inhibitory mediator on the secretion ofprolactin atthelevelofhypothalamus. Thisinhibition is mediated by $\mathrm{H} 2$ receptors ${ }^{(20)}$. Therefore the prolactin

stimulatory effect of Nigella sativa could be attributed to itsanticholinergic and antihistaminic actions.Furthermore, Nigella sativacontained high amounts of carbohydrate, oils, proteins and trace elements ${ }^{(2}$, 3). These contents represent a high energy sourceswhichcould participate in the galactagogue effect of Nigella sativa.Thehyperactivity of the breast tissue of the lactating miceonNigellasativa containing diet, occur due to an increase in the prolactinsecretion. Theseeffectswereclearly reflected on thelitterweight.According to these results, it appears that Nigella sativa is free from histological, haematological and biochemical side effects.Thesafety of Nigella sativa was recorded by manypreviousstudies ${ }^{(1,12,14)}$ However, thedeclinein theserum glucoseanduricacidwasattributedto hypoglycemic ${ }^{(12)}$, and hypouricemic effects of Nigella sativa ${ }^{(1)}$. 


\section{REFERENCES:}

[1]. Riaz ,M., Syed ,M. and Chaudbary , F. M. Chemistry of the medicinal plants of the genus nigella ( family Ranunculaceae ) Hamdard, XXXIX(2), $40-45$.

[2]. Al-Jassir ,M. S., Chemical composition and microflora of black cumin ( Nigella sativa L. ) seed growing in Saudi Arabia . Food Chemistry $1992,45,239-242$.

[3]. Al - Ani , A. H. J. , Astudy on the chemical component of local black seed ( Nigell sativa L ) and antimicrobial effect of its extract on some microorganisms , M. Sc. thesis , Al- Mustansiriya university , Baghdad 1998

[4]. Hanafy, M. S. and Hatem, M. S. and Hatem, M. E. studies on the antimicrobial activity of Nigella sativa seed (black cumin). J. Ethnopharmacology 1991,34 (2-3) 275-278.

[5]. Toppozada , H. H. , Mazloum , H. A. and El-Dakhakhny , M. The antibacterial properties of the Nigella sativa L. seeds. Active principle with some clinical applications, J. Egypt . Med. Assoc. 1965, 48 : suppl : 187-202 .

[6]. Toppozada , H. H. , Mazloum , H. A. and El-Dakhakhny , M. The antibacterial properties of the Nigella sativa L. seeds. Active principle with some clinical applications, J. Egypt . Med. Assoc. 1965,48 : suppl : 187-202 .

[7]. Mahfouz, M. , Abdel-Maguid, R. and El- Dakhakhny, IU. TheEffect Of Nigellone - therapy on the histaminopexic power of the blood sera of asthmatic patients . ArzneimForsch ( Drug Res. ) $1965,15,1230-1231$.

[8]. Chakravarty, N. Inhibition of histamine release from mast cells by nigellone, Annals of Allergy 1993, 70 (3), $237-242$.

[9]. Aqel, M. and Scheen, R. Effects of the volatil oil of Nigella sativa seeds on the uterine smooth musle of rat and guinea pig. J. Ethnopharmacol . 1996, 28 (1), 23-26.

[10]. El-Dakhakhny, M. studies on Egyptian Nigella sativa L.II some pharmacological properties of the seeds active principle in comparison to its dihydro compound and its polymer Arzneimittel- Forsch 1965, 15(10) 1227-1229.

[11]. El- Tahir, K. E. , Ashour , M. M. and Al- Harbi , M. M. . The cardiovascular actions of the volatile oil 0f the black seed Nigella sativa in rats :elucidation of the mechanism of action.Gen.Pharmacol . 1993, 24 (5), 1123-1131.

[12]. Al-Awadi , F. , Fatania , H. and Shamto, U. The effect of a plants mixture extract on liver gluconeogenesis in streptozotocin induced diabetic rats. Diabetes Res. 1991,18 (4), 163-168.

[13]. Janssen, M. R. , Tarasenko , A. , Lazovic, Getal . Abstract of Anti- angiogenic activity of Nigella sativa ( black seed ) plant extract in cancer therapy. Proc. Annu. Meet. Am. Assoc. Cancer Res. 1997, 38 , A1377 .

[14]. Kathi , A. and Kandel, A. Effect of Nigella sativa on immunity research of the $4^{\text {th }}$ international conf. in Islamic medicine, Kuwait 9-13. Nov. 1986

[15]. Worthen , B. R. , Ghosheh, C.A. and Crook , P. A. . The invitro antitumor activity of some crude and purified components of black seed, Nigella sativa . Anticancer Res. 1998, 18 (3A), 1527-1532.

[16]. Salomi , M. J. , Nair, S. C. and Panikkar, K. R. Inhibitory effects of Nigella sativa and saffron ( crocus sativa ) on chemical carinogenesis in mice. Nutr. Cancer . 1991, 16 (1), 67-72.

[17]. Agrawalla, Ip., Achar, M. V. S. , Boradkar, R. V. etal . Galactagogue action of cuminumcyminum and Nigella sativa . Ind. J. Med. Res. . 1968, 56, 841-844.

[18]. Snyder, G. , Mukherjee, A., McCann, S. M. Properties of muscarinic receptors of intact anterior pituitary cell. Fed. Proc. $1980,39,488$.

[19]. WEINER, R.J., Bethea, C.L. Hypothalamic control of prolactin secretion . In : Jaffe R Z B (ed), Prolactin. New York 1981,Pp 56.

[20]. Roberts , F. and calcutt, C.R. , Histamine and hypothalamus . Neuroscience 1983, 9,721-739. 